\title{
Vezetői életpályamodell a Magyar Rendörség kiválasztási rendszerében
}

\section{SZATMÁRI Adrienn ${ }^{1}$}

\begin{abstract}
A Magyar Rendőrség hivatásos állományának vezetői életúttal összefüggő kiválasztási rendszere egy összetett és többszintes folyamat, amely igen öszszetett munkajogi és szakterületi feladatokat tartalmaz. A személyi állomány hivatásos szolgálatra és ezáltal vezetői beosztásra történő egészségügyi, pszichikai és fizikai alkalmasságának felmérése a különböző alkalmassági vizsgálatok során történik meg, amelyek az egyén képességeire, készségeire és szervezeten belüli alkalmazhatóságára fókuszálnak. Ezen nézőpontot támogatja meg az újonnan bevezetett illeszkedésvizsgálat és a különböző kompetenciaalapú eljárások.

Jelen tanulmány a Magyar Rendörségen belüli vezetői életpályamodellhez kapcsolódó kiválasztási rendszert, annak legfontosabb bázispontjait, illetve az ezekhez tartozó kiválasztási folyamatokat, alkalmassági-vizsgálati rendszereket kívánja bemutatni. Kitér továbbá a hivatásos szolgálati jogviszony létesítésétől mint nullponttól kezdődő vezetői életpálya fontosabb lépcsőfokaira, azok feltételrendszerére, az integrált belügyi vezetőkiválasztási és vezetőképzési módszerre, illetve az ezeket átfogóan tartalmazó kompetenciaalapú képzési és kiválasztási rendszerre.
\end{abstract}

Kulcsszavak: rendőrség, vezetői életpálya, kiválasztás, alkalmassági vizsgálat, kompetencia

\section{Bevezető}

A Rendőrség vezetői életpályamodellje a közszolgálati életpálya, azon belül pedig a rendvédelmi életpálya része, ${ }^{2}$ amelynek feladata a szervezeti intézkedések mellett (például teljesítményértékelési rendszer), a hivatásos állomány képzési, továbbképzési és oktatási rendszerekbe történő bevezetésén túl a tagok szervezeti-vezetői szocializációja, a vezetői hivatástudat, és -etika kialakítása, fenntartása és a vezetői kompetenciák hosszantartó fejlesztése. A vezetői életúttal kapcsolatos kiválasztási eljárások megfelelő minősége hozzájárul a képzett és tapasztalt állomány fluktuációjának csökkentéséhez, ezáltal a hivatásos pálya megtartóképességének növeléséhez. Humánstratégiai

Szatmári Adrienn, Nemzeti Közszolgálati Egyetem Rendészettudományi Kar Rendészettudományi Doktori Iskola, doktorandusz.

Adrienn Szatmári, University of Public Service Faculty of Law Enforcement Doctoral School of Police Science and Law Enforcement, PhD student.

E-mail: SzatmariAd@fejer.police.hu, ORCID: https://orcid.org/0000-0001-8329-2026

2 Vári Vince: A rendőri életpályamodell és a rendőri felsőoktatás összehangoltsága. Magyar Rendészet, (2018), 2. 205222. 
szempontból bármely szervezet elsődleges érdeke az, hogy azokat válasszák ki egy vezetői beosztás tekintetében, akik alkalmasak annak betöltésére, illetve képességeik visszajelzésén, fejlesztési támogatásán keresztül hosszú távon legyenek a szervezet produktív tagjai.

\section{Jogszabályi környezet}

A Magyar Rendőrség vezetői életpályamodellje egy igen összetett és hosszantartó kutatómunkát követően az ÁROP-2.2.17-2012-2013-0001 azonosítószámú „Ưj közszolgálati életpálya” című kiemelt projekt keretein belül kidolgozott új, egységes vezetőkiválasztási rendszer kialakításával újult meg, ezzel biztosította azt az előmeneteli humánerőforrás-rendszert, amely a hivatásos állomány számára keretrendszerként szolgál a hivatásos állományba vételtől a vezetői beosztásba történő kinevezésig és annak fennállása alatt.

A vezetői életpálya rendszerét szabályozó lényeges rendeletek közül kiemelendő a 2/2013. (I. 30.) BM rendelet a belügyminiszter irányítása alá tartozó szervek hivatásos állományú tagjainak továbbképzési és vezetőképzési rendszeréről, valamint a rendészeti utánpótlási és vezetői adatbankról, amely osztályvezetői szinttől felfelé rendelkezik az adott beosztáshoz szükséges, előírt kiválasztási eljárások teljesítésének részleteiről és vezetőképzési követelményekről. ${ }^{3}$ Mindemellett a hivatásos állományba való tartozás egyik alapfeltétele, hogy a szolgálati követelmények érvényre juttatása tekintetében a személyi állomány tagja megfeleljen a 2015. évi XLII. törvény (IV. 24.) - a rendvédelmi feladatokat ellátó szervek hivatásos állományának szolgálati jogviszonyáról - követelményeinek, amely a szolgálati jogviszony feltételeinek részletezése kapcsán kiköti a szolgálat teljesítésére vonatkozó szabályokat, elvárásokat, valamint a kiválasztás kritériumait. A kiválasztás során folyamatosan vizsgált a hivatásos szolgálatra való pszichikai, egészségügyi és fizikai alkalmasság kérdése, amelyet a korábban, az új vezető-kiválasztási rendszer létrehívása idején az 57/2009. (X. 30.) IRM-ÖM-PTNM együttes rendelet - egyes rendvédelmi szervek hivatásos állományú tagjai egészségi, pszichikai és fizikai alkalmasságáról, közalkalmazotti és köztisztviselői munkaköri egészségi alkalmasságáról, a szolgálat-, illetve keresőképtelenség megállapításáról, valamint az egészségügyi alapellátásról - szabályozott, azonban 2021. január 1-jétől ez megújult és hatályba lépett a 45/2020. (XII. 16.) BM rendelet a belügyminiszter irányítása alatt álló egyes rendvédelmi feladatokat ellátó szerveknél foglalkoztatott hivatásos állomány és rendvédelmi igazgatási alkalmazotti állomány alkalmasságvizsgálatáról, illetve a 35/2020. (XII. 23.) ORFK utasítás a Rendőrség állományának alkalmasságvizsgálatáról is.

Malét-Szabó Erika: A belügyi vezető-kiválasztási rendszer tudományos megalapozása - avagy egy belügyi kutatás első eredményei. Pécsi Határör Tudományos Közlemények, 14. (2013), 141-149. 


\section{Elméleti háttér}

Amikor a kiválasztás fogalmával találkozunk, egy olyan információszerzési, előrejelző, döntés-előkészítő folyamatról beszélünk, amely során, ideális esetben egy adott munkakör betöltésére legalkalmasabb személyt választja ki a munkáltató a jelentkezők közül. ${ }^{4}$ A kiválasztási eljárás célja az egyéni különbségek feltárása, illetve a szükséges kompetenciák, képességek meglétének, minőségének felmérése. A kiválasztás a rendvédelmi szervek esetében a toborzást követő alkalmasság- és személyzeti/szervezeti vizsgálatokat tartalmazza, amelyek a tartósan, egyenletesen, átlagos szinten való teljesítés egészségügyi, pszichikai károsodás vagy baleset nélküli feltételeit teremtik meg.

A kiválasztás modelljei ${ }^{5}$ kapcsán elsőként Thorndike tradicionális elmélete emelendő ki, aki a munkát és az embert külön egységként kezelte, illetve a „megfelelő embert a megfelelő helyre” elvet hangsúlyozta. A modell a munkakörök elemzésével a hatékony munka kritériumait, valamint a beválás valószínűségét vizsgálta, később a munkahelyi elégedettség elméletének fogalmával is bővült. A dinamikus alapú kongruenciamodellek több aspektust vizsgáltak, amelyek közül elsőként kiemelendő Edwards személy-munka megfelelés modellje, amely két komponensre, a munka nyújtotta lehetőségekre, követelményekre, illetve az egyéni szükségletekre, elvárásokra helyezte a fókuszt. Dawis és Lofquist munkához való igazodás elmélete az egyén és a szervezet közötti kölcsönös megfelelést viszonyította, miszerint, ha a személy jól érzi magát a szervezetben, amiben dolgozik, jobb teljesítményre is törekszik, fenntartva a két oldal közötti összeillést. A legismertebb kongruenciamodell Holland nevéhez köthető, amely szerint az adott foglalkozású személyek hasonló személyiségszerveződéssel rendelkeznek, és különböző helyzetekben hasonlóan reagálnak, így a beállítódások különböző személyiségtípusokra oszthatók (például intellektuális, szociális). Csirszka alkalmassági megfelelés modellje a munka objektív tényezői (munkaprofil, munka érzelmi adottságai, munka dinamizmusa) mellett a szubjektív tényezőket (képességek, készségek, affektív adottságok, motiváció) is tartalmazta, amely tekintetében elsőként írták le az alkalmasságot egy lineáris dimenzió mentén, mégpedig négy fokozattal (abszolút, kiváló, átlagos, gyenge alkalmasság). A szelekciót hangsúlyozó modellek az egyénre fókuszálnak, miszerint az egyén személyiségét, képességeit minél jobban meg kell ismerni a hatékony alkalmazhatóság érdekében. A szocializációra összpontosító modellek pedig arra törekednek, hogy az egyén a munkahelyi szocializációs folyamat során egyre alkalmasabbá váljon az adott munkakör betöltésére, mivel az elméleti kontextus szerint szereptanulás révén sajátítjuk el a szervezeti normákat, elvárásokat. Ebben a tekintetben a kiválasztási eszközök nem a képességvizsgálatokon alapulnak, mivel mindenkire potenciális munkavállalóként kell tekintenünk, inkább a tanulóképesség feltárása a cél a későbbi, minél

Kővári György: Gazdálkodás az emberi erőforrásokkal. Budapest, Országos Munkaügyi Központ, 1991.

Hegedűs Judit: A vezetô-kiválasztás elméleti háttere. In Hegedűs Judit (szerk.): Tanulmánykötet a Belügyi Vezetô-Kiválasztási Eljárásról. Budapest, Belügyminisztérium, 2014. 5-9. 
eredményesebb alkalmazkodás, beválás érdekében. Így jutunk el végül a McClelland nevéhez köthető kompetenciaalapú kiválasztás elméletéhez, amely a hatékony munkavégzés és beválás előrejelzésére összpontosít. Hazánkban a rendvédelmi szervek is foglalkoztak korábban már a kompetenciaalapú kiválasztás lehetőségével (Twinning projekt), amely megalapozta a mai rendészeti kiválasztási eljárásokat és kompetenciaelméleteket. ${ }^{6}$

\section{Kiválasztási kritériumok a rendvédelmi szervek hivatásos állományába kerülés tekintetében}

A 2015. évi XLII. törvény (lásd: új Hszt.) a szolgálati viszony létesítésének feltételei között megszabja, hogy a rendvédelmi szervezet tagjának cselekvőképesnek, állandó belföldi lakóhelyú, magyar állampolgársággal rendelkező személynek kell lennie, aki a 18. életévét betöltötte (életkora a hivatásos szolgálat felső korhatáránál legalább tíz évvel kevesebb). A törvény szerint rendelkeznie kell továbbá meghatározott szakképzettséggel, hivatásos szolgálatra alkalmas egészségi, pszichikai és fizikai minősítéssel és a kifogástalan életvitel-vizsgálat, illetve - amennyiben szolgálati beosztása indokolttá teszi - a nemzetbiztonsági ellenőrzés pozitív, jóváhagyott eredményével. Általában véve tehát olyan személyről beszélünk, aki tudomásul veszi és elfogadja a hivatásos szolgálattal járó, szolgálati jogviszonyra vonatkozó szabályok által meghatározott kötelezettségeket, elvárásokat és egyes alapvető jogainak a szolgálati törvény általi korlátozását.

\section{A vezetői életpályát megalapozó rendészeti képzés}

A jelenlegi rendészeti oktatási rendszer az elmúlt évek, évtizedek során számos átalakításon, átszervezésen ment keresztül, ettől függetlenül a rendészeti képzés alapkon-

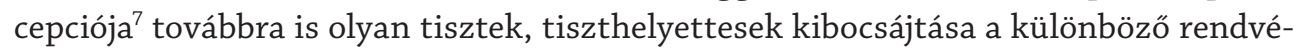
delmi szervek irányába, akik korszerű szakmai tudással, erkölcsi értékkel és emberi tulajdonságokkal rendelkeznek mind a hazai, mind a külföldi megfelelés érdekében. ${ }^{8}$ A jelenlegi képzési rendszer ezt a célt három szinten készíti elő és támogatja, amelyre a hivatásos jogviszonyú foglalkoztatás során épül a vezetőképzés rendszere.

Malét-Szabó Erika et alii: Rendőri alapkompetenciák az egységes közszolgálati alapkompetenciák tükrében. Rendörségi Tanulmányok, (2018), 1.15-74.

7 Boda József: A Nemzeti Közszolgálati Egyetem Rendészettudományi Kar feladatai a rendészeti képzésben. Határrendészeti Tanulmányok, 13. (2016), 1. 4-22.

8 Kovács Gábor: A Nemzeti Közszolgálati Egyetem alapképzésben végzett rendőrtisztekkel szemben támasztott követelmények változásai. Pécsi Határör Tudományos Közlemények, 17. (2016), 263-268. 


\section{Elökészítö képzés}

A hivatásos állományba való bekerülés, a kiválasztási rendszer bemeneti, előkészítő, tehát nulladik szintje az általános iskolai képzést követő, korábban középiskolai, majd szakgimnáziumi, jelenleg technikumi képzési rendszer. Az új szakképzési struktúra Rendészet és közszolgálat szakmacsoportja a rendészeti pálya iránt érdeklődő tanulók számára nyitott, akik olyan speciális ismereteket szerezhetnek ezáltal, amelyekkel pályaválasztásuk megalapozottá, felkészülésük célirányossá tehető. A képzési rendszer - amely során hangsúlyos a szakirányú módszerkompetenciák, képességek, készségek és szakmai ismeretek megalapozása - két év ágazati alapoktatást, majd három év szakirányú oktatást követően érettségivel és közszolgálati technikusi végzettség, tehát szakképzettség megszerzésével zárul. Ez a képzés opcionális, előny a szakirányú továbbképzés tekintetében, de nem előfeltétel. Sikeres elvégzése nem jelenti automatikusan a rendvédelmi szervek állományába történő bekerülést.

\section{Tiszthelyettesi képzés}

Az érettségi vizsga megszerzését követően a jelentkezőknek két képzési szinten van lehetőségük rendészeti oktatási intézménybe jelentkezniük, az egyik a tiszthelyettesi végzettséget biztosító Rendvédelmi Technikumok és a Rendőrség Oktatási és Kiképző Központ Rendőrképző Akadémia, a másik a felsőfokú, tiszti végzettséget nyújtó egyetemi képzés a Nemzeti Közszolgálati Egyetem Rendészettudományi Karán.

\section{Rendvédelmi Technikumi képzés}

A 2020-as év a rendőrképzés vonatkozásában egy újabb transzformációs pontot jelentett, az átalakult szakképzési rendszer következtében jelenleg a Körmendi, illetve a Miskolci Rendvédelmi Technikum biztosít technikumi rendőrszakképzést. Az új metódus a korábbi az OKJ-rendszerủ rendôr tiszthelyettes képzést váltotta, amely az érettségi vizsgát követően négy intézményben volt elérhető (Adyligeti, Körmendi, Miskolci és Szegedi Rendészeti Szakgimnázium) és Bünügyi rendőr, Határrendészeti rendőr, Közlekedési rendőr, valamint Közrendvédelmi rendőr szakirányú végzettséget biztosított.

A technikumi rendőr tiszthelyettes szakmára felkészítő szakmai oktatás ${ }^{9}$ tekintetében az alábbi időintervallumú képzések elérhetőek:

- amennyiben egy jelentkező előzetesen megszerzett tudás beszámítására nem jogosult, két tanéves képzési idejü szakképzésre jelentkezhet;

Körmendi Rendvédelmi Technikum: Tájékoztató a 2021/2022. tanévben induló 510321803 azonosító számú technikus szintü Rendốr tiszthelyettes szakképzettség megszerzésére irányuló 2 tanéves képzési idejü szakmai oktatás felvételi követelményeirôl és eljárási rendjérōl. 
- amennyiben rendészet és közszolgálat ágazati képzésben Fegyveres szervek és vagyonvédelmi ismeretek tantárgyat tanult, Rendészet ismeretek szakmai érettségi vizsgát tett és érettségi végzettséggel rendelkezik, vagy 2021. július 1-jéig Közszolgálati ügykezelő szakképesítést és Rendészeti és közszolgálati ismeretek ágazati szakmai érettségit szerez, előzetesen megszerzett tudás beszámítására jogosult, így másfél tanéves képzési idejű szakképzésre jelentkezhet;

- amennyiben rendészet és közszolgálat ágazati képzésben 2021. július 1-jéig Rendészeti ügyintéző szakképesítést és Rendészeti és közszolgálati ismeretek ágazati szakmai érettségit szerez, előzetesen megszerzett tudás beszámítására jogosult, tehát egy tanéves képzési idejű szakképzésre jelentkezhet.

Bármely időintervallumú képzési kategóriában kizárólag az a pályázó vehet részt, és azt veszik fel, aki a szükséges felvételi követelményeknek, a kiválasztási kritériumoknak, illetve a hivatásos szolgálati jogviszony feltételeinek maradéktalanul megfelel. A hivatásos szolgálat mint különleges foglalkoztatási, közszolgálati jogviszony számos feltételeket kíván meg tagjaitól. A korábban említett általános foglalkoztatási kritériumok mellett a Rendvédelmi Technikumba való jelentkezéskor, a hivatásos szolgálatra való alkalmasság megállapítása érdekében vizsgálat tárgyát képezi a büntetlen előélet és kifogástalan életvitel (saját magára, illetve közeli hozzátartozókra vonatkozóan), a múveltségi szint, a fizikai kondíció, az egészségügyi állapot és a pszichikai jellemzők. A felvételi eljárás fő pilléreként ez a komplex kiválasztási rendszer elég szigorú szűrőhálót jelent, tehát a rendőrség kifejezetten követelménytámasztó feltételeket szab pályázói esetében.

\section{Múveltségi és fizikai alkalmassági vizsgálat}

A 45/2020. (XII. 16.) BM rendelet (lásd: új BM rendelet) számos ponton módosította a korábbi felvételi eljárásrendet, így a 2021/22-es tanévtől kezdve a felvételi folyamat első állomása - a rendvédelmi technikumokban végrehajtva - a szakmai irányultságú általános múveltségi írásbeli vizsga (az előzetesen megszerzett tudás beszámítására nem jogosult jelentkezők számára), illetve fizikai (erőnléti) alkalmassági vizsgálat.

A szakmai irányultságú, elektronikus műveltségi teszt a jelentkező választott hivatásához kapcsolódó társadalmi, történelmi, állampolgári és igazgatási ismeretekben való jártasságot hivatott monitorozni. A teszt pontszám alapú, a jó válaszok $50 \%$ alatti aránya esetén kizáró jellegü.

A fizikai (erőnléti) alkalmassági vizsgálat során a jelentkezők erőnlétének, terhelhetőségének és fejleszthetőségének felmérése, megállapítása történik meg. A vizsgálat szintén kizáró jellegú és nemek szerint minimumfeltételeket határoz meg. A minimumfeltételek azon egészségi, pszichológiai és fizikai alkalmassági kategóriakövetelmények, amelyeknek minden hivatásos állományban lévő és oda jelentkezni kívánó 
személynek meg kell felelnie. Az alkalmasságvizsgálat során három gyakorlatot (20 méteres ingafutás; átugrás zsámoly felett, érkezés hason fekvésbe; falra dobás medicinlabdával) szükséges egymást követően elvégezni, amelyek mindegyikéből teljesítenie kell a felvételizőnek a neme vonatkozásában meghatározott minimumszintet. Alkalmas minősítés esetén a felvételiző, a feladatonként megjelölt nemek szerinti minimum ismétlésszámot teljesítette és a három feladatból összesen legalább nők esetében 80, férfiak esetében 100 ismétlést összegyűjtött. A teljesítés szerinti pontszám beleszámít a jelentkező felvételi pontszámába, így nemcsak a műveltségi szint, hanem a fizikai kondíció is igen fontos kritérium a kiválasztási eljárás során. A minimumpontok meghatározásán túl a fizikai alkalmassági vizsgálat az illeszkedésvizsgálat részét képező kompetenciavizsgálat eredményével együtt alkalmas a jelentkezők közötti rangsor meghatározására is.

\section{Egészségi és pszichológiai alkalmassági vizsgálat, személyügyi elbeszélgetés}

Második állomásként az a jelentkező, aki a rendvédelmi technikumokban a fizikai és a - szükség szerinti - múveltségi vizsgálaton megfelelt, illetve elérte a rendészeti technikum igazgatója által meghatározott előzetes ponthatárt, a lakóhelye vagy tartózkodási helye szerinti rendőri szervnél részt vesz az I. fokú egészségi és pszichológiai alkalmassági vizsgálaton, illetve személyügyi meghallgatáson. Lehetőség szerint ezt a három vizsgálatrészt egy napon bonyolítják le, így az alkalmasság minősítéséről a jelentkező még aznap kaphat visszajelzést.

A területileg illetékes alapellátó egészségügyi és pszichológiai szakterület a vonatkozó jogszabályok, szakmai protokollok és szabályzók szerint vizsgálja meg a jelentkezők alkalmasságát. Amennyiben a vizsgálatok negatív, „alkalmatlan” eredménnyel zárulnak, a pályázó fellebbezési lehetőséggel élhet. A II. fokú alkalmasságvizsgálatokért az Országos Rendőr-Főkapitányság Személyügyi Főigazgatóság Egészségügyi Szakirányító és Hatósági Főosztálya felelős, az esetlegesen itt meghozott, ismételten alkalmatlan minősítés kizáró jellegű.

A pszichikai alkalmassági vizsgálat alapvetően két részből, egy írásbeli és egy szóbeli feladatrészből tevődik össze, amelyek a rendeletben meghatározott pszichológiai minimumfeltételeket hivatottak vizsgálni. Az írásbeli vizsgálat során a jelentkezők intellektuális szintje (teljesítményteszt), személyiségmúködése (személyiségteszt), írásbeli kommunikációs készsége és anamnesztikus ${ }^{10}$ pszichológiai, egészségügyi adata, előzménye kerül górcső alá. A szóbeli vizsgálat részét képezi egy műszeres figyelemvizsgálat, egy egyéni prezentációs gyakorlat, illetve egy félig strukturált interjú is. $\mathrm{Az}$ írásbeli és szóbeli teljesítmény adatainak komplex értelmezése után a jelentkező

\footnotetext{
10 Anamnesztikus pszichológiai adat: élettörténeti előzmény, amely tartalmazza a tanulmányi, esetleges munkahelyi, családi, valamint releváns egészségügyi adatokat, életeseménybeli fordulópontokat.
} 
helyben kap visszajelzést az alkalmasságát érintően, illetve alkalmatlanság esetén tájékoztatást a jogorvoslati lehetőségekről.

Az egészségügyi alkalmassági vizsgálat során vizsgálandó, hogy a hivatásos szolgálat által megkövetelt fokozott egészségügyi igénybevételnek meg fog-e felelni a jelentkező, illetve a képzés elvégzését követően vagy annak ideje alatt e tekintetben hivatásos jogviszony létesíthető-e vele. Ennek felderítésére egy évnél nem régebbi tüdőszűrő-, labor-, hallásvizsgálat, szemészeti lelet, EKG-lelet, fogászati lelet, valamint az egészségi állapottal, illetve a korábbi betegségeivel kapcsolatos valamennyi dokumentum szolgál. Férfiak esetében szükséges még egy évnél nem régebbi urológiai vizsgálat, nők esetében pedig nőgyógyászati lelet és citológiai vizsgálat.

\section{Kompetenciavizsgálat}

Az egészségi, pszichológiai és fizikai képzési minimumfeltételeknek megfelelő és személyügyi szempontból nem kifogásolt, „alkalmas” minősítéssel rendelkező felvételiző ezt követően, egy másik időpontban részt vesz az illeszkedésvizsgálat részét képező kompetenciavizsgálaton. Az illeszkedésvizsgálat során a felvételizőnek a meghatározott szakterülethez és szolgálati beosztáshoz kapcsolódóan előre meghatározott kompetenciaelvárásokat, esetükben az egységes közszolgálati alapkompetenciáknak való megfelelésüket értékelik ki.

A kompetenciavizsgálat az új BM rendelet részletezésében a pszichológiai alkalmasságvizsgálat részét képező illeszkedésvizsgálat eleme, amelynek egyik típusa a rendészeti oktatási intézménybe jelentkezők esetében elvégzendő alapkompetenciavizsgálat, azonban a vezetői életpályán történő előrehaladással a hivatásos állomány tagjainak körében, adott beosztáshoz és karriereseményhez illeszkedően később megtörténik az irányítóikompetencia-vizsgálat, valamint a vezetőikompetencia-vizsgálat is.

Végezetül a személyügyi elbeszélgetést, amely a pályaalkalmasság személyügyi vizsgálatára szolgál, az állományilletékes parancsnok által kijelölt két-három fős bizottság végzi, optimálisan az alkalmassági vizsgálatok napjának végén.

Az alkalmassági vizsgálatokat követően a Nemzeti Védelmi Szolgálat elvégzi a kifogástalan életvitel ellenőrzését azok esetében, akik a szerzett pontszámuk és pluszpontszámuk szerint felvehetők. Az ellenőrzés során megtörténik az adategyeztetés, illetve a pályázó lakókörnyezetéből történő információk beszerzése annak érdekében, hogy megállapítsák, hogy a jelentkező életmódja, életvitele megfelel-e a jövőbeni hivatásos állományba vétel feltételeinek. 


\section{Felvételi döntés}

Utolsó lépésként a rendvédelmi technikumokban megtörténik a végleges felvételi ponthatár meghatározása és a felvételi döntés. A felvételi bírálatot támogatva, az alkalmasságvizsgálatot végző személynek - amely ebben az esetben a rendvédelmi alapellátó pszichológusokat jelöli - a képzési minimumfeltételeknek való megfelelést követően illeszkedésvizsgálatot, és a jelentkezők sorrendbe állítását kell megtennie a kompetenciavizsgálat és a fizikai alkalmassági vizsgálat eredményei szerint. Ez a sorrend a döntésre jogosultat, tehát a rendvédelmi technikum állományilletékes parancsnokát nem köti, vezetői döntést támogató információnak tekintendő.

\section{Rendörség Oktatási és Kiképzö Központ Rendörképzö Akadémia}

A szakmai alapoktatás mellett a két rendvédelmi technikummal együtt a ROKK Rendőrképző Akadémiájának Szegedi, illetve Adyligeti Járőrképző Tagozatán a 2020. szeptemberben induló tanévtől kezdődően van lehetőség rendőrjárőr szakképesítést is szerezni. A tíz hónapos időtartamú, nappali rendszerû képzés első két hónapjában munkavállalóként, majd ezt követően szolgálati jogviszonyban állóként vesznek részt a jelentkezők az oktatásban, amelynek sikeres elvégzését követően közbiztonsági rendőrjárôr és határrendész és útlevélkezelő rendőrjárőr képesítést szereznek. A felvételi folyamat esetükben - az intézményi módosítást kivéve - megegyezik a rendvédelmi technikumokra vonatkozó kritériumokkal.

\section{Tisztképzés}

Harmadik szinten a hivatásos állomány képzéséért a felsőoktatási rendszeren belül a Nemzeti Közszolgálati Egyetem Rendészettudományi Kara felelős, amely 2012. január 1. napjától a Rendőrtiszti Főiskola jogutódjaként vesz részt a rendészeti képzésben. ${ }^{11} \mathrm{~A}$ korábbi, jogelőd intézmények (Rendőrtiszti Főiskola, Zrínyi Miklós Nemzetvédelmi Egyetem, Budapesti Corvinus Egyetem Közigazgatástudományi Kar) integrációjának és átalakításának célja egy olyan egyetem létrehozása volt, amely markáns bázist jelent az államtudományi, közszolgálati szakemberképzésben. ${ }^{12} \mathrm{~A} \mathrm{Nemzeti}$ Közszolgálati Egyetem Rendészettudományi Kara ennek mentén biztosítja a Rendőrség, a Büntetés-végrehajtási Szervezet, az Országos Katasztrófavédelmi Főigazgatóság, az Országos Idegenrendészeti Fởigazgatóság, a Nemzeti Adó- és Vámhivatal,

11 Kovács Gábor: A Nemzeti Közszolgálati Egyetem, mint a közszolgálati képzés bázisa: a jelenlegi helyzetkép, jövőbeni változások, fejlődési tendenciák és kihívások. Pécsi Határőr Tudományos Közlemények, 13. (2012), 371-378.

12 Kovács Gábor: A rendészeti képzések rendszere a Nemzeti Közszolgálati Egyetemen. Határrendészeti Tanulmányok, 13. (2016), 1. 23-36. 
valamint a magánbiztonsági szféra különböző területein meghatározott szakirányú felsőfokú végzettséget igénylő munkakörök betöltéséhez szükséges képzést.

Jelenleg a kar hallgatói tanulmányaikat az egyetemi tájékoztatók és szabályzatok szerint nappali és levelező munkarendben három-, illetve négyéves alapképzési, valamint levelező munkarendben kétéves mesterképzési szakon folytathatják, továbbá a 2016/2017 tanévtől a rendészeti képzésekre nappali munkarendre felvett hallgatók már „tisztjelölt” jogállásban tanulnak. ${ }^{13}$

A Rendészettudományi Kar alapképzései: Bűnügyi igazgatási alapszak, Bűnügyi alapképzési szak, Rendészeti igazgatási alapszak, Rendészeti alapképzési szak, Katasztrófavédelem alapszak, Polgári nemzetbiztonsági alapképzési szak. A Rendészettudományi Kar mesterképzései: Rendészeti vezető mesterképzési szak, Kriminalisztika mesterképzési szak, Katasztrófavédelem mesterképzési szak, Polgári nemzetbiztonsági mesterképzési szak, Biztonsági szervező mesterképzési szak.

A felsorolt szakok általában véve vett célja olyan szakemberek képzése, akik szakmai és vezetői felkészültségük alapján alkalmasak a rendvédelmi feladatokat ellátó szerveknél beosztotti és vezetői feladatok ellátására, azonosulni tudnak a szervezet elvárásaival, és kellő mélységű ismeretekkel rendelkeznek a képzésük folytatásához. A szakirányokat alapvetően az különbözteti meg egymástól, hogy a hallgatók tanulmányaik folytatása során melyik rendvédelmi szerv, illetve a civil biztonsági szféra melyik szolgálati ágában végzendő tevékenységre nyernek felkészítést. ${ }^{14}$

Az egyetemen megtalálható szakirányú továbbképzési szakok közül kiemelendő a Rendvédelmi szervező szakirányú továbbképzési szak, amely a Rendőrség, a Katasztrófavédelem, a Büntetés-végrehajtási Szervezet állományában tiszti beosztású, vagy abba tervezett, felsőfokú végzettséggel rendelkező, de felsőfokú rendészeti szakképzettséggel nem rendelkező személyek számára nyitott. A képzés feladata olyan tudás átadása, amelynek segítségével a hallgatók képesek a különféle rendvédelmi szervezetek felépítését, működését és irányítását naprakész és komplex vezetésés szervezéselméleti ismereteken keresztül elsajátítani. ${ }^{15}$

2016-tól a Nemzeti Közszolgálati Egyetemen lehetőség van rendészeti doktori képzés folytatására is, amely a felsőfokú képzési rendszer legmagasabb szintje. A Rendészettudományi Doktori Iskola kiemelten az államtudományok, a közigazgatás, a biztonság és védelempolitika, a hon- és a rendvédelem területein kutatók számára biztosít lehetőséget a tudományos fokozat megszerzésére, hozzájárulva az oktatói és kutatói, tágabb értelemben a tudományos szakemberképzéshez. ${ }^{16}$

A Nemzeti Közszolgálati Egyetem Rendészettudományi Karára történő jelentkezés feltételei némiképp eltérnek a felsőoktatási szabályozás következtében a rendvédelmi

13 Boda (2016) i. m.

14 222/2019. (IX. 25.) Korm. rendelet az államtudományi képzési területen szerezhető képesítések jegyzékéről és a képzések képzési és kimeneti követelményeiről.

15 Nemzeti Közszolgálati Egyetem Rendészettudományi Kar: Rendvédelmi szervezô szakirányú továbbképzési szak Képzési és Kimeneti Követelmények. Szakfelelős: Dr. Balla József egyetemi docens, Nemzeti Közszolgálati Egyetem, 2018.

16 Nemzeti Közszolgálati Egyetem Rendészettudományi Kar Rendészettudományi Doktori Iskola: Doktori felvételi tájékoztató. Budapest, 2019. 
technikumok rendelkezéseitől, közös pont azonban az alkalmassági vizsgálati rendszer teljesítésének követelménye. Kiemelendő, hogy a nappali rendészeti képzésre 18-25 éves, a rendvédelmi szervek hivatásos állományú tagjai esetében 30 évesnél nem idősebb, magyar állampolgárságú, magyarországi lakóhellyel rendelkező személyek jelentkezhetnek, illetve a legtöbb szak esetében elvárt egy államilag elismert, középfokú (B2) komplex típusú nyelvvizsga bizonyítvány a meghatározott nyelvek egyikéből, vagy egy ezzel egyenértékú érettségi bizonyítvány felmutatása.

A tiszti képzés felvételi eljárásának metodikája megegyezik a tiszthelyettesi képzés protokolljával, a személyügyi és minimumfeltételek (fizikai, egészségügyi és pszichológiai alkalmassági vizsgálat) teljesülésének meglétét követően sor kerül a felvételt támogató sorrendállítást eredményező illeszkedésvizsgálatra, amely a kompetenciavizsgálat és fizikaialkalmasság-vizsgálat által eredményezett, számszerűsíthető eredmények összessége.

\section{Az alkalmassági vizsgálatok rendszere a hivatásos szolgálat fennállása alatt}

A hivatásos szolgálatra való munkaköri alkalmasságot a szolgálati jogviszony létesítését megelőzően, illetve fennállása alatt rendszeresen vizsgálni és minősíteni szükséges, amelynek szabályozására az 45/2020. (XII. 16.) BM rendelet hivatott.

A fizikai, egészségi és pszichológiai alkalmassági vizsgálatokat a rendvédelmi szervek személyügyi, illetve egészségügyi és pszichológiai szakterületénél, a szakirányító szervek vonatkozásában kidolgozott és az országos rendőr-főkapitányság vezetője által jóváhagyott szakmai protokollok szerint végzik el. Az egészségi alkalmasságot orvos, a pszichológiai alkalmasságot pszichológus, a fizikai alkalmasságot egészségmegőrző és sportfoglalkozások, edzésprogramok vezetésére jogosító képesítéssel rendelkező, vagy fizikai alkalmasság felmérésében szerzett kétéves gyakorlattal rendelkező személy bírálja el.

A testi-lelki egészség és állóképesség biztosítása érdekében a rendvédelmi állomány vonatkozásában az alábbi alkalmassági vizsgálatokat célzottan szükséges elvégezni a hivatásos szolgálati jogviszony fennállása alatt, illetve azt megelőzően, amelyeket I. fokon a területi szervek alapellátó szakterülete (kivéve az utolsó), II. fokon az ORFK végez:

- hivatásos állományba kinevezést megelőző;

- véglegesítés előtti;

- kategóriaváltáshoz kapcsolódó;

- vezetői szolgálati beosztásba kinevezést megelőző;

- időszakos;

- soron kívüli;

- ismételt és

- külszolgálathoz kapcsolódó alkalmasságvizsgálat. 
Az alkalmasságvizsgálatok beosztási kategóriákhoz illeszkednek, és minimumfeltételeken túl további fizikai, egészségügyi vagy pszichológiai követelményeket is tartalmazhatnak. A 35/2020. (XII. 23.) ORFK utasítás részleteiben rendelkezik a rendszeresített szolgálati beosztások alkalmasságvizsgálati kategóriába sorolásáról (utasítás 1. melléklete), a BM rendelet pedig az egészségi, pszichológiai és fizikai minimumfeltételeket ismerteti (rendelet 1., 2. és 4. melléklete), illetve a képzési minimumfeltételekre is kitér (rendelet 5., 6., 7. melléklete).

Általánosságban elmondható, hogy egy 4×3-as felosztási felosztási rendszerben jelennek meg a beosztási kategóriák, az I-IV. kategóriába a beosztotti, az V-VIII. kategóriába az irányítói, a IX-XII. kategóriába a vezetői beosztást betöltő állománytagok sorolódnak. Az irányítói beosztást betöltő személy (például csoportparancsnok, alosztályvezető-helyettes, szolgálatparancsnok) az állomány több tagját látja el közvetlenül feladattal, amely új vizsgálati szegmensként jelenik meg a kiválasztási eljárásokban.

A támogató szerepkörök (I., V., IX. kategória) a rendvédelmi feladatok alapfeladatába nem tartozó, főként adminisztratív, illetve operatív feladatokat ellátó beosztások, amelyek képernyő előtti, hivatali munkarendű szellemi munkavégzést jelölnek fokozott felelősséggel, döntési kényszerrel, figyelmi terheléssel. Az adminisztratív/ hatósági szerepkörök (II., VI., X.) szintén nem alapfeladatként megjelenő, főként belső térben végzett szellemi munkával, alapvetően hivatali rendben történő szolgálatteljesítéssel, valamint könnyű vagy közepesen nehéz fizikai és pszichikai megterheléssel járó beosztások. A beavatkozó/intézkedő (III., VII., XI.) szerepkörök közepesen vagy nehéz fizikai munkával, fokozott fizikai és pszichés megterheléssel (például zajterhelés, fokozott balesetveszély lehetősége) járó beosztások. Végül a speciális szerepkörök (IV., VIII., XII.) fokozott fizikai igénybevételt és jellemzően speciális egészségi és pszichikai megterhelést tartalmaznak.

A rendelet további új eleme a korábban már említett illeszkedésvizsgálat, illetve kompetenciavizsgálat, amely az alkalmasságvizsgálatokkal együtt a Kétlépcsős Integrált Alkalmasságvizsgálati Rendszerben, vagyis a KLIR rendszerben valósul meg. Az adott szolgálati beosztás által megkívánt alkalmas minősítés fenntartását az alkalmassági vizsgálatok mentén meghatározott fejlesztési tervek (például kompetenciafejlesztés a továbbképzési rendszerben), egészségfejlesztés és -megőrzés, valamint mentálhigiénés gondozás és támogatás segíti.

\section{Az alkalmassági vizsgálatok aktualitása}

Látható, hogy a különféle alkalmassági vizsgálatok folyamatosan végigkísérik a hivatásos állomány tagjainak, ezáltal a rendészeti vezetők karrierútját egészen a felszereléstől kezdve a nyugdíjba vonulásig. Már a felvételt megelőző vizsgálatok is számos területen monitorozzák a jelentkezők hivatásos szolgálatra való alkalmasságát, legyen ez valamelyik tiszthelyettesi oktatási intézmény vagy a Nemzeti Közszolgálati 
Egyetem. A rendészeti oktatási intézménybe való felvételt megelőző alkalmassági vizsgálatot a hivatásos állományba való kinevezés követi, amely a tanulók/hallgatók esetében akár már a képzés időszaka alatt megtörténhet vagy a kettős jogviszony (NKE RTK tisztjelölt) vagy például a munkavállalói státuszból történő kinevezés következtében (10 hónapos rendőrjárőr képzés). A véglegesítés előtti alkalmassági vizsgálat a hivatásos állományba vételt követő próbaidő letelte után esedékes, amely kapcsán a gyakorlati helyen töltött tapasztalatnak, illetve a parancsnoki véleményezésnek is igen nagy szerepe van. Eddig a pontig, a Rendőrség állományába történő végleges bekerülés határáig, az alapellátó orvosnak, pszichológusnak és sportszakembernek lehetősége van kiszűrni a szakterületi vizsgálatok során a szervezetben eltöltött gyakorlati idő és parancsnoki véleményezésre támaszkodva azt, hogy kik azok, akik megfelelő készségekkel, képességekkel és tulajdonságokkal rendelkeznek, ezáltal hatékony tagjai lehetnek a rendőri szerveknek. ${ }^{17}$ A véglegesítésre vonatkozó vizsgálatot követően az új BM rendelet egységessé tette a kötelező időszakos alkalmassági vizsgálatok gyakoriságát, 30 éves kor alatt háromévente, 30 éves kortól kétévente történik meg a hivatásos állomány testi-lelki állapotának felmérése. Az alapellátó szakterület dolgozói így rendszeres időközönként meggyőződhetnek arról, hogy az állomány tagjának aktuális állapota lehetővé teszi-e a készségeinek, képességeinek megfelelő teljesítményt, avagy támogatásra, gondozásra, fejlesztésre vagy valamilyen szakellátásra van-e szüksége mindennek eléréséhez. ${ }^{18}$ A 2021-es évtől új vizsgálati elemként jelenik meg a kategóriaváltáshoz kapcsolódó alkalmassági vizsgálat, amelyre abban az esetben kerül sor, amikor a hivatásos állomány tagjának beosztási kategóriája módosul, például vezetői beosztásba nevezik ki. Amennyiben a hivatásos szolgálati viszony fennállása alatt az egészségügyi és pszichés egyensúly valamifajta instabilitása tapasztalható, az állományilletékes parancsnok elrendelhet soron kívüli alkalmassági vizsgálatot is. Ez a fajta vizsgálati metódus egyrészt az aktuális testilelki állapot felmérésére, illetve az egyensúlyi működésmód visszaállításának módjára és lehetőségeire fókuszál, másrészt pedig a kiválasztási eljárások, alkalmassági vizsgálatok revíziójára, a beválás kritikai értékelésére is szolgál.

A különböző vizsgálatok módszertana eltérő területekre fókuszál, amelyek kapcsán az alkalmasságnak való megfelelés vagy kétpólusú (alkalmas-alkalmatlan, alkalmas-alkalmatlan a tervezett szolgálati beosztásra, alkalmas-alkalmatlan a tervezett vezetői beosztásra), vagy pedig az alkalmas-alkalmatlan minősítésen túl soron kívüli alkalmasságvizsgálat megindításával ideiglenes alkalmatlan, esetleg új eredményként korlátozással alkalmas kategóriával zárul. Az ismételt alkalmasságvizsgálat ezen vizsgálat és az állapotbeli javulás felülvizsgálatára szolgál.

17 Szabó Erika: A munkahelyi egészségpszichológia és egészségfejlesztés rendszere a Magyar Köztársaság Rendôrségén, valamint a szubjektíve észlelt munkahelyi stresszterheltség jellegzetességei - különös tekintettel az idôi tényezöre - a hivatásos állományú rendôrök körében. Doktori értekezés. Debrecen, Debreceni Egyetem, 2010.

18 Malét-Szabó Erika - Szatmári Adrienn: A rendőr lelki biztonsága - avagy a biztonság megőrzésének egyik alappillére a rendôr lelki biztonsága. Pécsi Határôr Tudományos Közlemények, 13. (2012), 399-412. 


\section{Vezetői szolgálati beosztásba kinevezést megelözó vizsgálatok}

A szolgálati jogviszony vezetői beosztás felé vagy a vezetői szinten belül történő módosítására abban az esetben kerül sor, ha a rendvédelmi szerv tagja rendelkezik a vezetői beosztáshoz szükséges szakmai és rendvédelmi ismeretekkel, vezetői kompetenciákkal, továbbá fizikai, egészségi és pszichológiai állapota is alkalmassá teszi a beosztás betöltésére. A hivatásos szolgálati törvény továbbá megköti, hogy a kiemelt vezetői és középvezetői szolgálati beosztásba történő kinevezés feltétele a rendészeti szakvizsga, a rendészeti vezetővé képző, illetve a rendészeti mestervezetővé képző tanfolyam sikeres teljesítése.

A vezetői szolgálati beosztásba kinevezés előtt szükséges - pszichológiai alkalmasságvizsgálat keretén belül - illeszkedésvizsgálatot is elvégezni, hogy az adott vezetői beosztás sajátosságaihoz milyen mértékben illeszkedik a jelölt kompetenciaprofilja, tehát a tervezett vezetői beosztás jövőbeli hatékony betöltése várható-e tőle. Adott beosztásra több jelentkező esetén rangsorállítással választják ki a legalkalmasabb, legmegfelelőbb kompetenciákkal rendelkező személyt, amely a kinevezésre jogosult vezetőt döntésében nem köti. Az elvégzett kompetenciavizsgálat eredményei alapján meghatározhatóak a fejlesztendő területek, valamint egy egyéni fejlesztési terv öszszeállíthatóvá válik.

A rendvédelmi szervek osztályvezető vagy annál magasabb szintű vezetői esetében szükséges az adott vezetői szint esetében előírt vezetőképzési követelmények sikeresen teljesítése is. Az új és egységes vezetőkiválasztási rendszert 2012-2014 között egy komplex és szervezetspecifikus kutatás alapozta meg a Belügyi Tudományos Tanács és a BM Oktatási, Képzési és Tudományszervezési Főigazgatósága közremúködésével. A széles körű tudományos munka során kidolgozták a 13 egységes belügyi vezetői kompetenciát és az ÁROP-2.2.17-2012-2013-0001 azonosítószámú „Új közszolgálati életpálya” címú kiemelt projekt keretén belül egy összetett informatikai rendszer által támogatottan, azok mérésére szolgáló módszertani eljárásrendet. Jelenleg a vezetőkiválasztási eljárás a Belügyminisztérium Rendészeti Vezetőkiválasztási, Vezetőképzési és Továbbképzési Főosztályán működik. Az egységes belügyi vezetői kompetenciákat két szinten határozták meg, középvezetői (osztályvezető és főosztályvezető-helyettes), illetve felsővezetői szinten (főosztályvezető, illetve magasabb beosztási szint) történt a fogalomalkotás. A struktúra egyesíti az átfedésben lévő és elkülönülő, vezetők felé támasztott elvárásokat, méri az egyéni, a társas és az elsődlegesen vezetői kompetenciákat.

Az egységes vezetői kompetenciákat a 45/2020. (XII. 16.) BM rendelet 3.1. melléklete az alábbiak szerint részletezi.

Egyéni vezetői kompetenciák:

I. szakmai ismeret: szakmai elméleti ismeretek; szakmai összefüggések, folyamatok ismerete; testületismeret (hely- és személyismeret); szakmai tapasztalatok; 
II. következetesség, kiszámíthatóság: szabálytudat, fegyelmezettség; elvárások támasztása, következetesség;

III. cél- és feladatorientáltság: tudatos, adekvát konfliktuskezelés; érdekképviselet és -érvényesítés; felelősségvállalás;

IV. kreativitás, innováció: kreativitás, innováció; nyitottság, ösztönzés;

V. rendszerszemlélet, lényeglátás: elemző gondolkodás, lényeglátás; rendszergondolkodás; stratégiai gondolkodás;

Társas vezetői kompetenciák:

VI. döntési képesség, felelősségvállalás: döntés-előkészítés; döntéshozás;

VII. rugalmas alkalmazkodóképesség: változó helyzethez való alkalmazkodás; pszichés terhelhetőség, hatékony stresszkezelés;

VIII. reális önismeret, önfejlesztési igény: reális önismeret; önfejlesztési igény;

IX. kommunikációs készség: célok meghatározása; feladatok személyhez kötése;

X. konfliktuskezelés, érdekérvényesítés: személyre szabott motiválás, fejlesztés; személyészlelés, empátia, tolerancia; hatékony együttmúködés megteremtése;

Vezetői kompetenciák:

XI. munkatársak motiválása, fejlesztése: személyre szabott motiválás, fejlesztés; személyészlelés, empátia, tolerancia; hatékony együttmúködés megteremtése;

XII. vezetői funkciók ellátása: tervezés, szervezés; irányítás, koordinálás, ellenőrzés;

XIII. személyes példamutatás: hitelesség; szervezet iránti elkötelezettség; minőségre törekvés, igényesség.

\section{Összefoglalás}

Jelen tanulmány a rendvédelmi szervek vezetői életpályája vonatkozásában tekintette át a kiválasztási eljárásokat, illetve az ezekhez tartozó aktuális jogszabályi módosításokat. A rendvédelmi pálya iránt érdeklődő és vezetői ambícióval rendelkező személyeknek alapvetően két módon van lehetőségük a rendvédelmi szerv hivatásos állományába tartozni, ezt a célt a tiszthelyettesi vagy a tisztképzés rendszerébe történő bejutással érhetik el. A Nemzeti Közszolgálati Egyetem elvégzését követően a hivatásos állomány tagja vezetői beosztás betöltésére jogosulttá válik, amelynek előzménye lehet egy tiszthelyettesi vagy tiszti beosztáshoz társuló irányítói beosztásban eltöltött idő és megszerzett szakmai tapasztalat. Az osztályvezetői szinttől kezdődő vezetői beosztást betöltők esetében feltétel a vezetőkiválasztási eljáráson való részvétel, illetve a középvezetői, később a mestervezetői rendészeti vezető képzés sikeres teljesítése. A hivatásos állományú jogviszony fennállása alatt a vezetői beosztásban történő hatékony múködésmód megtámogatására a rendvédelmi szervek alkalmassági 
és kompetenciavizsgálatai hivatottak, az ezekhez tartozó támogató, segítő szervezeti-szakterületi intézkedések pedig aktív fejlesztési lehetőséggel rendelkeznek.

\section{FELHASZNÁLT IRODALOM}

Boda József: A Nemzeti Közszolgálati Egyetem Rendészettudományi Kar feladatai a rendészeti képzésben. Határrendészeti Tanulmányok, 13. (2016), 1. 4-22.

Hegedűs Judit: A vezető-kiválasztás elméleti háttere. In Hegedűs Judit (szerk.): Tanulmánykötet a Belügyi Vezetö-Kiválasztási Eljárásról. Budapest, Belügyminisztérium, 2014. 5-9.

Kovács Gábor: A Nemzeti Közszolgálati Egyetem, mint a közszolgálati képzés bázisa: a jelenlegi helyzetkép, jövőbeni változások, fejlődési tendenciák és kihívások. Pécsi Határôr Tudományos Közlemények, 13. (2012), 371-378.

Kovács Gábor: A rendészeti képzések rendszere a Nemzeti Közszolgálati Egyetemen. Határrendészeti Tanulmányok, 13. (2016), 1. 23-36.

Kovács Gábor: A Nemzeti Közszolgálati Egyetem alapképzésben végzett rendőrtisztekkel szemben támasztott követelmények változásai. Pécsi Határör Tudományos Közlemények, 17. (2016), 259-264.

Kővári György: Gazdálkodás az emberi erőforrásokkal. Budapest, Országos Munkaügyi Központ, 1991.

Malét-Szabó Erika - Szatmári Adrienn: A rendőr lelki biztonsága - avagy a biztonság megőrzésének egyik alappillére a rendőr lelki biztonsága. Pécsi Határőr Tudományos Közlemények, 13. (2012), 399-412.

Malét-Szabó Erika: A belügyi vezető-kiválasztási rendszer tudományos megalapozása - avagy egy belügyi kutatás első eredményei. Pécsi Határôr Tudományos Közlemények, 14. (2013), 141-149.

Malét-Szabó Erika - Hegyi Hella - Hegedűs Judit - Szeles Erika - Ivaskevics Krisztián: Rendőri alapkompetenciák az egységes közszolgálati alapkompetenciák tükrében. Rendőrségi Tanulmányok, (2018), 1. 15-74.

Szabó Erika: A munkahelyi egészségpszichológia és egészségfejlesztés rendszere a Magyar Köztársaság Rendörségén, valamint a szubjektíve észlelt munkahelyi stresszterheltség jellegzetességei - különös tekintettel az idői tényezőre - a hivatásos állományú rendörök körében. Doktori értekezés. Debrecen, Debreceni Egyetem, 2010.

Vári Vince: A rendőri életpályamodell és a rendőri felsőoktatás összehangoltsága. Magyar Rendészet, (2018), 2. 205-222.

\section{Jogforrás}

222/2019. (IX. 25.) Korm. rendelet az államtudományi képzési területen szerezhető képesítések jegyzékéről és a képzések képzési és kimeneti követelményeiről

\section{Internetes források}

Körmendi Rendvédelmi Technikum: Tájékoztató a 2021/2022. tanévben induló 510321803 azonositó számú technikus szintü Rendör tiszthelyettes szakképzettség megszerzésére irányuló 2 tanéves képzési idejű szakmai oktatás felvételi követelményeiről és eljárási rendjéről. Online: www.krvt.hu/ index.php?start $=40$

Nemzeti Közszolgálati Egyetem Rendészettudományi Kar: Rendvédelmi szervező szakirányú továbbképzési szak Képzési és Kimeneti Követelmények. Szakfelelős: Dr. Balla József egyetemi 
docens, Nemzeti Közszolgálati Egyetem, 2018. Online: https://rtk.uni-nke.hu/document/rtkuni-nke-hu/Rendv\%C3\%A9delmi\%20szervez\%C5\%91\%20szakir\%C3\%A1ny\%C3\%BA\%20 tov\%C3\%A1bbk\%C3\%A9pz\%C3\%A9si\%20szak\%20k\%C3\%A9pz\%C3\%A9si\%20program.pdf Nemzeti Közszolgálati Egyetem Rendészettudományi Kar Rendészettudományi Doktori Iskola: Doktori felvételi tájékoztató. Budapest, 2019. Online: www.uni-nke.hu/document/uni-nke-hu/ doktori-felveteli-tajekoztato-2019.pdf

\section{ABSTRACT}

\section{Leadership Career Model in the Selection System of the Hungarian Police} Adrienn SZATMÁRI

The leadership career-related selection system of the professional staff of the Hungarian Police is a complex and multi-level process, which includes much combined labor law and professional tasks. The assessment of the health, mental and physical suitability of staff for professional service and thus for management positions takes place through various aptitude tests that focus on the individual's abilities, skills and applicability within the organization. This aspect is supported by the newly introduced fit test and competency-based procedures.

The present study aims to present the selection system related to the leadership career model within the Hungarian Police, its most important base points, as well as the selection processes and aptitude examination systems. It covers the most important stages of a leadership career, starting from the establishment of a professional employment relationship, as a zero point, their system of conditions, the integrated interior leadership selection and training method, and the competency-based training and selection system that comprehensively includes them.

Keywords: police, leadership career, selection, suitability examination, competence 